【論 文】

UDC : 72.01
日本建築学会計画系論文報告集 第 433 号・1992 年 3 月 Journal of Archit. Plann. Environ. Engng, AIJ, No. 433, Mar., 1992

\title{
テオ・ファン・ドゥースブルフの言説からみた共同体意識 COMMUNITY CONSCIOUSNESS FROM THE POINT OF VIEW OF THEO VAN DOESBURG'S STATEMENTS
}

\author{
崔 在 錫* \\ Jaesuk CHOI
}

〈De Stijl〉 Movement begins in company with the foundation of the 〈De Stijl〉 Periodical. It is worthy of notice that This Movement started with the consciousness of community lead to developing by way of the $\langle\mathrm{De}$ Stijl〉 Architecture Movement, according to Theo van Doesburg (1883 1931)'s concern of archiecture.

This study examines into his view of architecture with the actions and statements of Theo van Doesburg that kept out leader's role, in the terms of publication of This Periodical. As for This Movement, Theo van Doesburg's statements could look for the different aspect in every period, but it is the express of consciousness to community, in addition to the spirit of the times, from the beginning to the last of This Movement.

Theo van Doesburg's statesments on the consciousness of community came to create the elements of the architecture plastic, and these came out of the nature of duality. Concretely, it is able to analyze Theo van Doesburg's community consciousness apply to the principle of sensus communis. Finally, It studies the character of architecture community

Keywords : community (= gemeenschap) consciousness, duality, sensus communis 共同体意識, デュアリティ，センスス・コムニス

\section{はじめに}

本研究は，〈デ・スティル〉運動において指導的な役 割を果したテオ・ファン・ドゥースブルフ Theo van Doesburg, 1883〜1931 (以下, ドゥースブルフという) の言説の中の共同体意識の形成とその変化の過程から, 彼の建築観を考察することを目的とする。

〈デ・スティル>運動は, 建築, 絵画, 文学などの諸 芸術の統合を目指す建築家 J. J.P.アウト，画家ヴァ ン・デル・レック, ピエト・モンドリアン, 詩人アント ニー・コックがくデ・スティル>創刊誌に記事を発表す ることによって始まった。芸術共同体として出発した 〈デ・スティル >運動は, ドゥースブルフの建築への強 い関心と運動に参加した建築家らとの共同作業によっ て, 次第に諸芸術の統合より建築運動へ変わっていき", ヴァン・デル・レックを初めとして，他分野の芸術家た ちは次々にくデ・スティル〉誌から離脱する。ドゥース ブルフの一方的な建築志向は，〈デ・スティル〉に参加 した画家らとの関係を難しくし, 初めに見られた芸術共 同体としてのくデ・スティル>の性格は, 次第に建築運
動としてのくデ・スティル〉建築共同体へと転換してゆ く。ドゥースブルフは, 〈デ・スティル〉に参加した芸 術家に彼らの芸術思想をくデ・スティル〉誌に寄稿する 機会を与える役割を果たした。

ドゥースブルフは,「面家, 䧓刻家, 建築家, 暂学者, 批評家, 講演者, 理論家, 劇作家, 印刷者, 詩人, 小説 家」と言われているが21 <デ・スティル〉誌刊行中の ドゥースブルフの活動之言説を見ると，画家や建築家と

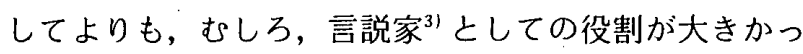
たことに気づく。芸術運動の一環として，〈デ：スティ ル〉誌の刊行を主宰したドゥースブルフは，その刊行期 間中, 自らの作品制作よりは，芸術作業における「共同 体」gemeenschap ${ }^{4}$ の必要性を意識した言説が目立って いる。本論文では，「個人は他者なしには存在し得な い $ل^{5)}$ という言説を中心に，これと同義の言説を取り上 げ，考察する。これらは，〈デ・スティル〉誌 (1917〜 1931）の中に収められている。彼の初期の言説は普遍的 な共同体的性格を持っていたが，次第に建築を意識した 共同体的性格へと変化していく。彼の言説が変化して 
いった主要な要因は，何よりも，ドゥースブルフ自身の 建築造形への関心が強かったことと，画家らとの理念的 な差が大きかったためと思われる。

本稿は,ドゥースブルフの言説の特徴を,「共同体意識」 community consciousness ${ }^{6)}$ として位置付け，これらの 言説の変化を論じ, ドゥースブルフの建築観を明らかに するものである。

\section{I. ドゥースブルフの言説の背景}

本稿で取り上げるドゥースブルフの重要な言説とは, 「内的な生活の中での統一体」”，「美の新しい思想を拡 大するために，社会では，精神的な共同体が必要であ るゴ,「個人は他者なしには存在し得ない」,「自己の破 壊（第一）と人生に対する一つの実在の姿勢のそれ（第 二）なしには，文化的もしくは個人的な完成に至る向上 はあり得ない」9)などを指す。ここで，これらの言説が ビのような背景を持ち, ドゥースブルフの意識の中で定 着していったかについて，一般的な概念を加えて検討す る。

共同体 (community) とは，もともと社会学的な概念 で, 思想, 理解力などの共通, 一致, 類似という意味と して理解されている。それは, 人間の共同生活（政治, 文化，歴史をともにする社会) を一体のものとしてとら えた概念である。このような共同体を意識した活動や理 念は, 近代に入って, 社会学的な面にとどまらず，その 概念, 理論, 方法にもとづいて, 思想, 哲学, 芸術を含 めた全体像として発展してきた。田中喬は，「人間の要 求は, 集団において行為され, 満足される。近代集団に おいては,これらの要求充足は, 概して機能的な面から 人為の集団に結び付く $ل^{10)}$ 之語る。彼は, 近代の建築活 動の行為を個人性によるものではなく，共同体（集団の 協同性）によるものとして意識している。こうした共同 体を形成する基本的な手段や姿勢には，個人的な感覚や これを超える意識が要求されているのである。

これまでの芸術活動は, しばしば個人主義として位置 付けて論じられている場合が多い。しかし，あらゆる方 面において共同体の形成なしに，個人の活動はあり得な い。これから，ドゥースブルフが芸術活動における共同 体の必要性を意識したことに注意し，前に言及した ドゥースブルフの言説の中で, 特に,「個人は他者なし には存在し得ない」(以下, 個人=他者と略する) とい う言説を取り上げ,この言説がゼのような背景を持って いるかを探っていきたい。「個人=他者」の関係は，個 人は他者の存在によって初めて自己を意識し，個人だけ では存在し得ない「共に」という概念に基づき成立する。 つまり, 個人は他者を意識した後に, 初めて社会性が生 じるのである。芸術活動においても，このような限界を 越えることはできない。ドゥースブルフの「個人=他者」
という言説は, 彼自身の問題だけではなく, 古くから哲 学者らの重要な課題でもあったのに気付く。例えば, 有 名なデカルトの「われ思う，ゆえにわれ在り」という言 説は, 自己が思惟するものを指しているが，これは，個 人は他者の存在を確認することで, 自己を意識すること を示している。このようなデカルトの思惟する自己には， 根本的に個人のみにとどまらない「人間共同体」の意味 が含まれている。つまり，ドゥースブルフの「個人=他 者」の関係の形成は，皮相的な結合によるものではなく， デカルトの言う「思う二精神」によっている。ドゥース ブルフのこのようなデカルト的な精神世界は, <デ・ス ティル>創刊誌の紹介文の中で, その雑誌の刊行目的や 〈デ・スティル〉運動の活動目標を「美の新しい思想を 拡大するために，社会では，精神的な共同体が必要であ る」と明確に表明しだ言説を見ても読み取ることができ る。近代に入っても, デカルト的な思考体系が見られ， 哲学者フッサールは，「われわれは，何ら注意を向けな いうちから，われわれの隣人や一般に知人たちからなる 限られた核とともに，われわれ仲間の共同体の開された 地平を意識している。その際われわれの外部地平の人た ちも，そのつどく他者〉，すなわちそのつどくわたくし にとって〉, 〈わたくしの>の他者として共に意識され ている」と論じる"1”。ッサールの「くわたくしの>の 他者」とは人々との共存を意味し，ドゥースブルフの「個 人=他者」の言説と同じ方向であるのが分かる。つまり， ドゥースブルフの「個人=他者」の言説は, これまで取 り上げた社会的な概念や哲学者らの言説を背景にして形 成されたのである。くデ・スティル>期間中のドゥース ブルフの中心的な課題は, 芸術活動において共同体形式 をとっていかに展開することができるかであった。こう した潜在的な意識は, 実際にドゥースブルフの論文の中 で, 共同体的意味を持つ言説として数多く表明されてい る。

筆者は, ドゥースブルフの論文に見られる共同体的言 説を共同体の必要性を意識した言説と位置付け, 本稿で は，これを，共同体意識と名づける。

ここで,これまでのドゥースブルフの言説がどのよう な性格を持っているか述べておく。芸術の問題において, 知覚, 身体, 言語, 時間, 空間などは, 生活, 技術, 文 化, 思想と強く関わっている。しかし,こうしたものは, ある個別的な現象によってはとらえることができず, 全 体的な知覚によってのみとらえられる。これを「共通感 覚」sensus communis（以下，七ンスス・コムニスとい う）と呼ふふ2121。このセンスス・コムニスとは, 本来, 習 慣や型の解体・形成との絡み合いのなかで働くものとし て理解されている。これを, 中村雄二郎は,「センスス・ コムニスとは, 諸感覚（センスス）に相渉って共通（コ ムニス)で，しかもそれらを統合する感覚，私たち人間 
のいわゆる五感（視覚, 聴覚, 嗅覚, 味覚, 触角) に相 渉りつつ，それらを統合して働く総合的で全体的な感得 力,つまり共通感覚のことだったのである」染立定義し ている。すなわち，センスス・コムニスはそれ自体が一 種の感覚でありながら, 同時に個別感覚, つまり五感の 一つ一つを越え，個別諸感覚を相互に関係づけ，秩序付 け，統合へ向かう動きを持つことを指している。

ここで, ドゥースブルフの共同体意識を表わす代表的 な言説，「個人=他者」の関係の形成に，七ンスス・コ ムニスの性格が関与しているかどうかについて検討す る。ドゥースブルフの言説に見られる「超意識」「超個人」 「超感覚的規則」の中の「超一」という概念は, センスス・ コムニスの性格を持っている。特に, センスス・コムニ スへの接近は, あらゆる問題の中で, それらの「個別的 な現象」としての認識ではなく、「全体的な知覚」とし ての認識である。つまり,ドゥースブルフの言説,「個 人=他者」は，「超一」と言う意味を持ち，これは個人 の知覚によるものではなく，「個人=他者」の共通的な 知覚によって形成されるものである。このようなセンス ス・コムニスを美意識として表したカントの「美的共通 感覚」sensus communis aesthetics ${ }^{14)}$ を取り上げ，それ をドゥースブルフの「個人=他者」の意識との関わりを 検討する。カントは，「美的共通感覚」の中の「三つの 段階」5゙で「あらゆる他人の立場に立って考えること (判断力)」の意味について言及している。これは, 自 分自身を他者の立場におく能力, 言い換えれば,「自二他」 の関係を意味する。カントはセンスス・コムニスを「共 同体的感覚」gemeinschaftlichen sinnes ${ }^{16)}$ と呼んでいて, 美を倫理的で社会的な機能を持つ社会的な次元として意 識し, 社会の内でこそ生じるものとして意識している。 これは, 根本的に人間相互関係 (共同体) の媒介による 美の生成を意味する。こうしたカントの美に対する社会 的な観点は, ドゥースブルフの言説の中の「個人=他者」 関係の形成にまで拡げられるのである。

以上，ドゥースブルフの言説を取り上げ，その背景を 共同体の社会学的な概念や哲学者らの言説に関連させて 考察をした。

\section{II. 〈デ・スティル〉誌以前のドゥースブルフの言説}

ドゥースブルフは，1913 年を前後にして，芸術共同 体の必要性を意識し始める。ここではくデ・スティル $>$ 誌の刊行 (1917) 以前に活躍した建築家や芸術家の活動 や言説を彼がどのように読み取っていたかについて考察 する。

1912 年まで, ドゥースブルフは, 芸術批評活動とと もに絵画などの作品制作を行なっていた。しかし, 彼は, 1912 年 7 月から雑誌『エーンハイド』に寄稿した『新 しい批評主義に対する例』という論説の中で，「芸術は
外的な美によるものではなく, 純粋で深い感情を表現す る能力によって判断すべきものである」豆)と述へ，それ までの彼自身の考え方や作品の事実性に疑問を抱き始め る。ところで，こうしたドゥースブルフの意識の変化は, I章で取り上げたように，潜在的には，哲学者の思想を 基にしながら，現実的には，20世紀初めに活躍した建 築家や芸術家たち, 特に，H.P. ベルラーへ，W. カン ディンスキー, F.T. マリネッティらの著書や作品から の影響が強いと思われる。ここで, 彼らの言説のいくつ かを取り上げ, ドゥースブルフの言説との関連性を探る ことにする。カンディンスキーは；「およそ自然現象の 模倣になんらの目標もおか妘術家，すなわ方，自己の 内面的な世界を表現しょうとし，(中略）各芸術はそれ ぞれ各自固有の能力を持ち, しかもこれは, 他の芸術の 能力によって代理させることのできぬものであることが 判る。こうして最後には, 各種の芸術がもつ固有の能力 が, 統合されるようになる」吕 と述へ，芸術家の創作行 為は，自然現象そのままの描写を意味するのではなく， 芸術家の精神体験を表現する内面的な指向であると, 彼 は強調している。ドゥースブルフは，「人間の内面的な 生活が秩序であり, 芸術家はそのなかで, 創造すること である。なぜ，内的な生活のなかで統一体として表現さ れるか」界と述べており,この言説は, カンディンスキー の「内面的な世界」と通じることが分かる。ドゥースブ ルフは, フランスのキュビスム, イタリアの未来主義, ドイツの表現主義などの絵画を「病的で, 残忍で, 唯物 主義的な形式である」20) と非難している。しかし，1913 年に「エーンハイド』に寄稿したエッセイの中で「絵画

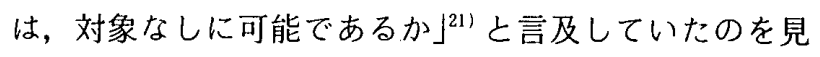
ると, 彼の芸術に対する意識がすでに外的な対象から内 的な対象へと変わっていたことが分かる。1914年になっ てからドゥースブルフは，批評活動や作品制作の目標を 内面性に置いて展開する。つまり，ドゥースブルフは, 1912 年から 1914 年の間に, 芸術の内面的な世界を意識 しながら，絵画の新しい形態を目指したのである。その 後，ドゥースブルフは，1914 年から 1916 年まで，第一 次世界大戦のために兵隊に入ることになったが, このこ. とが, 彼にとって, 多くの人々と出会うキッカケを作っ $た^{221}$ 。兵営生活では余裕があったため, 兵役にういてい た地域の芸術家たちとの交流を進めていくの中で, ドゥースブルフの活動は, 共同体的な活動へと変わる。 こうした活動の中で, ドゥースブルフは, 名芸術家を結 ぶ手段として雑誌発刊の必要性,を意識する。つまり, ドゥースブルフは, 雑誌こそ, 芸術家と芸術家との交流 や, 芸術家と大衆とのコミュニケーションの役割を果た す重要な手段であると意識した。これが，後にくデ・ス ティル>誌の創刊の発端まで至る。また, 彼は, 雑誌の 刊行の意志だけではなく，実質的な芸術家の集合による。 
共同体的な活動を重要視し，いくつかの「芸術共同 体」231 を次々と創立し，自ら中心的な活動を始める。と ころが，彼は，〈デ・スティル〉誌の創刊まで，建築設 計を行なったことがなく，建築家アウトから『デ・ヘウ ス八ウス』（1916）の内部デザインを頼まれ，この建物 における通路の床，入口の門と壁面の色彩計画を行なっ ただけである。つまり，〈デ・スティル〉誌の創刊メン バーとなったアウトとの共同作業のみが, 1916 年まで の建築家や建築の仕事と関わった活動のすべてであっ た。

一方, オランダの建築家ベルラーへは, <デ・スティ ル>に直接関わった証拠はないが, 彼の過去様式にとら われない建築思想は，〈デ・スティル〉に参加した建築 家だけではなく，オランダの建築家たちに強い影響を与 えている。特に，〈デ・スティル〉創刊に参加したアウ トは, ベルラーへの事務所に勤めたこともあって, 彼の 作品の中には, ベルラーへの建築の影響が見られる。 ドゥースブルフ自身は, ベルラーヘとの直接関係はな かったが，ベルラーへの事務所に勤めた建築家らとの共 同作業によって, ベルラーへの思想と接する。ドゥース ブルフは, ベルラーへの建築より, 彼の著書を通じて, ベルラーへが新しい建築を意識していることに気づいて いた。ここで, ベルラーへの言説の中にある共同体的表 現の断片を探ってみよう。ベルラーへは，「建築的布局 (komposition) の確定は幾何学的な基礎の上になさな ければならない。建築的形態は幾何学的自然でなければ ならない。自由な理解, 解积にしたがって, しかし最も 単純な適確な方法を以て発展しなければならない。それ ゆえにローマの建築は反省しなければならない。何とな れば, 彼においてはただギリシヤの形を反射しているの みで, その精神, 永久に真理である構造的建築法則であ るその精神を反射していないから。(中略) それは，個 人的でなくてそれ自身だけで美しい。はなただしく個人 的なものに時々見る個性の醜さを超越しているから」 と語っている。このベルラーへの言説で注意すべきこと は, 建築様式より，時代の要求に基づく建築様式を強調 した点にある。これは，旧習の非合理性や伝統的な考え 方を排撃したものと思われるが，必ずしも，過去のすへ てを否定したという意味ではない。こうしたベルラーへ の共同体的言説では，彼が，新しい建築のあり方を，個 人の様式によるものではなく，ある程度社会的な要請に 応じる必要性があることを意識していることに注目した い。ベルラーへのこのような共同体意識への接近は，「絵 画と彫刻は建築に仕えるものとして共に前進すべきであ る」占) と述べた彼の言説を見ても，彼が芸術における共 同体の必要性をいかに強く感じていたかが分かる。

つまり，1916 年までのドゥースブルフの共同体意識 は，カンディンスキ一の内面的な世界やべルラーへの様
式における時代精神認識との出会い，そして，多くの芸 術家たちとの芸術活動における共同体の必要性を自覚し た後に生まれたものである。その後，ドゥースブルフの 共同体意識は, カントらの思想を背景に，くデ・スティ ル>結成の基本理念を形成していく。ここで, ドゥース ブルフの言説の中で, いくつかの共同体的言説を見てみ よう。ドゥースブルフは,「芸術的な創造性を通じた人 類への転換，個人的な原理から共同体の原理への運動， 精神的な共同体を導く有機的なス夕イルの発展」26)につ いて語り，このような目標に至るために，「芸術は，人 間と神の間の中間媒体として奉仕すべきである」 ${ }^{271}$ と強 調する。また，〈デ・スティル>誌の文章の中で，「本 誌は，(中略）新しい創造的な造形芸術に関する今日の 諸思潮一本質的で実際には同一であるが，個人的に展開 して来た諸思潮を統合させることを目的とする」と表 明している。〈デ・スティル〉研究者として知られてい る H.L.C. ヤッフェも，「〈デ・スティル〉運動は, 1917 年夏の始め頃より, そのグループ員の芸術作品と 言説の間の共同関係を特色とするようになった」 291 と評 している。すなわち，ドゥースブルフは，彼自身の作品 制作はもちろん，芸術家たちが作った雑誌による大衆と 芸術家，または芸術家と芸術家との関係の形成を重視し たのである。

こういう思想は, 〈デ・スティル〉誌の刊行期間に, 彼の文章の中で共同体的言説として現われる。次章では， これらの言説を中心に,その変化を考察することにする。

\section{III. 〈デ・スティル>誌前半期のドゥースブルフの言説 と共同体意識}

これまで, ドゥースブルフの言説の背景やくデ・ス ティル>誌以前の言説の変化について考察してきた。本 章では,〈デ・スティル〉誌に載っている彼の様々な言 説の中で, 普遍的な性格を持つ共同体的言説を考察する とともに, 彼が, 〈デ・スティル〉運動とどのように関 わっていたかについて論じる。

〈デ・スティル〉誌刊行は, 1915 年 10 月, アムステ ルダムの市立美術館で, ドゥースブルフが，モンドリア ンの作品「CompositieX』（1915）を観覧したのがきっ かけとなっている。ここで, ドゥースブルフは, 同じ意 識を持っている芸術家たちがいることに気づき，1916 年 2 月モンドリアンを訪問し, 雑誌の計画に参加するよ う呼びかけた。その年, モンドリアンを始め, 画家ヴっ ン・デル・レック, フッサール, 建築家アウトらは, ドゥースブルフの主幸の下でくデ・スティル〉誌に共同 寄稿することによって,グルーブ活動を始める。ドゥー スブルフは, 〈デ・スティル>創刊誌の巻頭文 ITER INLEIDING』（1917）を奇せている。これを見ると, 彼の共同体意識が明確に表明されている。「造形芸術の 
新しい意識を具体的な共同体に基づいて，この雑誌は， 芸術文化の方法を準備する。すべての造形芸術の分野に おいて，芸術家たちが相互に同じ現実化に至った時，彼 らは共通言語 (aglemeene taal) を語ることになる。そ の時，彼らは最早，彼ら自身の個人性に執着することは ないだろう。つまり彼らは普遍的な原理を取り，制約さ れた個性への関心を示されない。普遍的な原理によって， おのすからら有機的なスタイルが生まれる。美の新しい思 想を拡大するために，精神的な共同体 (geestelijke gemeenschap）が, 社会には必要である。そして, 精神 的な共同体は，個人主義の㬢性なしには現れないだろ う」30。 。゙ゥースブルフは，〈デ・スティル>誌の刊行 目的と運動の方向を「共同体」の理念と関連させて述べ ている。つまり,ドゥースブルフの共同体意識は, くデ・ スティル>運動の方向として位置付けられ，〈デ・ス ティル>誌を通してて, 様々な言説として表われ，変化し ていく。このようなドゥースブルフの言説は, 諸芸術活 動における時代性と個人性の意識のズレから生まれた変 化である。言い換えれば、ドゥースブルフは，くデ・ス ティル〉誌を「共同体」の普遍的原理を生み出す手段と してとらえ，それまでの個人主義ではなく,くデ・スティ ル>誌を通じた諸芸術間の新しい関係，また諸芸術と大 衆との新しい関係の形成を強調したのである。時代精神 と個人主義のズレから生じたドゥースブルフの共同体意 識は，〈デ・スティル>誌刊行中の彼の中心的な言説と して位置付けられ，初期の思想的な共同体的言説から様 式を意識した共同体的言説へと展開していく。以下で， こうしたドゥースブルフの共同体的表現の様々な側面を 取り上げ，変化の過程を考察する。

ドゥースブルフは，「私の文筆の目的は，大衆ととも に論理的な説明と新造形芸術を防衛し，大衆とともに厳 しい攻撃に備えるためにある」尚と言い，また，「芸術 家たちは，作品制作だけではなく，彼ら自身が，言葉に よって大采に話しかける」321 と語る。こうしたドゥース ブルフの共同体的意味を持つ言説の展開は, ドゥースブ ルフが, 「大衆は作品制作や言説の共同関係を忘れた芸 術家たちを非難する。芸術家たちとの関係は共同体 (community) へと転換する。その転換のキッカケは社 会意識である」33) と言及していることを見ても，彼がど れほど共同体の必要性を感じていたかを読み取ることが できる。ドゥースブルフの言説の性格は, <デ・スティ ル〉運動の最初宣言, 『くデ・スティル〉宣言 I」(1918) にも表われている。この宣言で，彼は「古い時代意識と 新しい時代意識とがある。古い時代意識は個人的なもの へ向かう。新しい時代意識は普遍的なものへ向かう。個 と普遍との争いは世界大戦にも現代芸術にもあらわれ る。新しい芸術は, 新しい時代意識の内容をあらわにし た。普遍と個との均衡のとれた関係がそれだ。新しい時
代意識はすべてのもののうちに，外面的な生のうちにす らあらわれようとしている」吕と表明している。この宣 言の中の「古い一個人，新しい一普遍」や「個と普遍」 というデュアリティ的な言説から，相対的な面から新し い関係を創出しようとする彼の「共同体への意志」が見 られる。実に，この宣言 I の言説は，いずれも，〈デ . スティル>創刊誌で表明した「精神的な共同体」の概念 から発展した具体的な表現で，共同体を指向する彼の強 い意志が見られる。この宣言で, 彼は創作行為の目標を 客観的で普遍的な過程を通じたものにする必要があると 強調する。宣言に見られるドゥースブルフの芸術創作活 動の目標は, 自らが芸術作品を作る際, 過去のものを真 似したり，個人の意志によって創りだしたりはしないこ とにある。この宣言Iによって，〈デ・スティル〉活動 の目標は具体的に形成され, 雑誌創刊以後, 彫刻家や建 築家の新しい参加によって, 総合的性格を持つものとし て発展していく。

これまでに取り上げたドゥースブルフの言説の中心的 な内容は,「精神的な共同体」「社会意識」「普遍と個と の関係のとれた均衡」などであるが，『建物の二つの断 片に関する記念碑的芸術についての覚書』（1918）の初 めにある「個人は他者なしには存在し得ない」という言 説は，芸術共同体の条件としての言及ではなく，広く普 遍的な共存の概念から述べている言説である。I章で， 筆者は,こうしたドゥースブルフの言説の背景として， 社会学的概念や哲学者の言説を引用しながら,ドゥース ブルフの言説,「個人=他者」の関係を検討した。つまり， ドゥースブルフが芸術共同体の必要性を強調した言説の 中には，現実的な問題意識だけではなく，哲学的な概念 も含まれているとした。ドゥースブルフが, 初めて「個 人=他者」の関係に言及した背景は, 彼自身がくデ・ス ティル>誌の創刊以前から共同関係をもっていた建築家 アウトとの共同作業を実現した喜びと彼自身の共同体意 識であった。こうしたドゥースブルフの言説は; くデ・ スティル>誌の初期だけではなく, 以後のくデ・スティ ル>運動の中心的な理念を形成していく。彼の他の記事, 『集団的な芸術とその社会的重要性」(1927 ${ }^{351}$ にも，繰 り返して「個人は他者なしには存在し得ない」の言説が 見られる。

また，未来派の F.T. 、リネティの影響が見られる 『The other face』(1920) $)^{36)}$ という小説では, ダダイズ ムの文学活動を超感覚的な規則 (supersensual rules) として位置付け, 自らダダイズムのような文学活動を行 なうている。こうしたドゥースブルフの自覚は，ただ 〈デ・スティル〉誌前半期にとどまらず，〈デ・スティ ル>運動期間を通じ続くが, 1922 年前後に, ドゥース ブルフは, 建築造形の形態的な問題に積極的な関心を示 すようになる。つまり，イエナ，ワイマール，ベルリン 
で行なった講演『様式への意志』(1922)で，あらゆるデュ アリティ現象の対立から，中庸（the golden mean）の 法則を基にする「両極端の和解」や「多極性の合意」に 言及し「様式のために，個人的な表現としての芸術作品 ではなく，民族の共同体的な表現としての芸術のため に」年という言説では，前に取り上げた『くデ・スティ ル>宣言 I』の「個と普遍」のデュアリティ的関係の均 衡や共感の認識から具体化された新しい様式への意志が 見られる。ここで，これまでしばしば取り上げた共同体 意識の性格やその条件と言えるデュアリティについて言 及しておくことにする。ドゥースブルフは，「その物質 的現実化に対する新しい美学から』(1923) で，「われわ れの人生に対する意識は,デュアリティの破壊を要求し， 統一のため, 不可分の普遍的現実のための必要性を感じ, 物的表現によって, 自由な芸術の理想的な美学が指摘さ れてきたものを，建築で実現しようとするものであ る」38) と語る。ドゥースブルフのデュアリティに関する 意識は, 〈デ・スティル>創刊誌に載せたモンドリアン の論文、『絵画における新しい造形』(1917) の中の「関 係のデュアリティ」 dualiteit derverhouding ${ }^{391}$ の概念か ら生じ出たものである。ドゥースブルフとモンドリアン との関わりの梁さを知ることができる。モンドリアンが 「自然と精神，女性的原理と男性的原理，否定的と肯定 的, 静的と動的, 水平と垂直」ととらえているのに対し て,ドゥースブルフは「垂直と水平, ‘男性と女性, 空間 と時間, 静的と動的, 八ーモニーとメロディー」として とらえている(0)。すなわち，この二人のデュアリティに 関する言説では，モンドリアンがデュアリティを普遍的 な関係から連続的な進化, 換言すれば,「発生, 抎張, 衰退」の循環による関係として意識したのに対して, ドゥースブルフはこれらの要素間の共感的な性質として 理解しているのである。また, ドゥースブルフは, 『様 式への意志」で,「不確かさにかわる確かさ，閉鎖性に かわる開放，曖昧さにかわる明晰教義，宗教的権威にか わる宗教的活力, 美にかわる真理, 複雑さにかわる単純 さ，形にかわる関係，分析にかわる総合，抒情的配列に 加る論理的構築, 手仕事にかわる機械化, 模做之装飾 的潤色にかわる造形的形態，個人主義にかわる集合主 義」」1) と, デュアリティの性格や条件における様式を 語っている。

この言説は, その後,〈デ・スティル〉建築展の論理 的な展開, 『造形的建築を目指して』（1924）の内容の基 になる。そして，ムードン (Meudon) のアトリエを完 成した 1930 年頃の論文, 『新しい建築とその結果」 $(1930)^{421}$ にも，再び彼の独特な共同体意識のデュアリ ティ的性格がうかがえる。こうしたドゥースブルフの言 説を見ると，〈デ・スティル〉誌初期の普遍的な共同体 意識が, 次第に様式への意識として転移されていくのが
分かる。このようなドゥースブルフの言説の変化の原因 は，偶然ではない。ドゥースブルフはくデ・スティル〉 誌を編集しながら，画家を中心とする諸芸術家に，彼ら の芸術思想をくデ・スティル〉誌に寄稿するよう勧めた が, 画家としてのドゥースブルフは, 〈デ・スティル〉 に参加した建築家アウト,ヤン・フィルス,ファン・トッ フ, デ・ボール, エーステレンらとの共同作業の中から 生まれたのである。このような意識の変化から,ドゥー スブルフは, 様式の創造的な過程を，「図解（あるいは 模做）をやめ, 美学的な変形 (概念作用) によって, 別 の世界に入る事である」 ${ }^{43)}$ と言う。この言説の中の「変 形原理」とは，共同作業による創造過程を指している。 つまり,デュアリティからの均衡, 合意が要求されるの である。こうした意識は，次のドゥースブルフの言説に

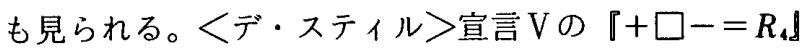
（1923）で，「共同体的な努力の過程を通じて, 我々は, すべての芸術（技術や産業を除外して）による造形的統 一体として研究して来た。その結果, 我々は新しい様式 を生み出すことになった」 ${ }^{44)}$ と語り，また「宣言V」の 注解として発表された『共同的な構造に向かって」(1923) では,「現実の生活から分離された幻影としての芸術思 想は消减しなければならない。(中略) そして, 新しい 造形的な統一体へと導いている。それらは総合的活動の 過程を通じ，また，実験によってのみ観察され得るので ある」451 と語っている。

ところが，こうしたドゥースブルフの共同体意識は, 1926 年まで，〈デ・スティル〉と関わっていたモンド リアンによって, 否定的な側面として取り上げられる。 モンドリアンは, 『家, 街路, 都市』(1927) という記事 で,これまでのドゥースブルフの共同体意識を,「個人は, 今日のように集団の中にいるかぎり，調和ある物的な環 境を生み出すことはできない。(中略) 今日，あたかも 空間によって隔てられていないかのごとく共同生活を送 られる人々が既にいる。しかし，そうした能力は集団に は期待しえないし，目下のところ何ものも待ち望むこと ができない。実のところあらゆるものは，個人から，そ して個人によって生み出されている」 ${ }^{46)}$ と非難してい る。モンドリアンは, 〈デ・スティル〉誌の創刊から『絵 画における新しい造形」を発表するなど，くデ・スティ ル〉理念の軸となっていたが，このようなモンドリアン の言説は, ドゥースブルフの共同体意識と大きな隔たり を見せている。つまり，ドゥースブルフがモンドリアン の理念を背景に，彼の理論を建築の実験的方法論として 考えたのに対して，モンドリアンは，絵画や絵画に関す る造形論のみに関して言及し，その理論は，形式論に止 まっていた。ドゥースブルフは,「我々の目的は, 統一 体としての組織体としての媒体の組織である(形態, 造 形主義を創造する)」五) と, 一貫して, 創造過程の手段 
として芸術作業における共同体の必要性を説き続ける。 本章の考察は，主にくデ・スティル〉運動の前半期を 対象としてきたが，共同体意識に関する言説では，建築 の本質を具体的に追求し，その属性を分析的にとらえよ うとする姿勢は希薄であった。つまり,〈デ・スティル〉 誌前半期のドゥースブルフの言説は, 建築の本質からの 追求ではなく，社会学的な面，言い換えれば，共同体的 な側面から建築をとらえようとしたのが特徴である。そ の原因は，・゙ゥースブルフが，画家あるいは建築家の， どちらにも属さない曖昧な立場にあったことと，芸術家 の社会的な責任や芸術の時代的な要因を強く意識しすぎ たことにあった。

\section{V. 〈デ・ズティル〉誌後半期のドゥースブルフの共同 体意識と建築観}

本章は，ドゥースブルフの共同体意識が建築観として どのように転移してきたかを，〈デ・スティル〉誌の後 半期の言説を中心に，探るものである。ここで取り上げ るドゥースブルフの建築に関する言説は，III章と同じ 〈デ・ステ.ィル〉誌刊行期のものであるが, 後半期に, ドゥースブルフは建築に関する言説を多く残している。 ドゥースブルフの共同体意識は，一方では，今日われわ れがごく普通に使う共同体の普遍的な概念，「個人=他 者」の概念から社会性を指向し, 他方では, センスス・ コムニスへの接近によって，あらゆるデュアリティ要素 が均衡, 統合, 統一, 合意, 中庸, 克服, 和解亡なるも う一つの共同体意識を様式の概念と見なしうる語義まで に拡張した。例えば，I章で引用した「個人は他者なし には存在し得ない」に見られる共同体意識や，四章で引 用した「普遍と個との均衡のとれた関係」様式のために, 個人的な表現としての芸術作品ではなく, 民族の共同体 的な表現としての芸術のために」に見られる共同体意識 は, 明らかに, 普遍的な共同体概念が様式の共同体的言 説として転移されていることを示している。つまり， ドゥースブルフの共同体意識は, 普遍的な意識から様式 への意志へ，また様式への意志から建築観へと移り変 わってゆく。このようなドゥースブルフの言説の変化は, 彼が建築こそ総合芸術であると意識し，〈デ・スティ ル>誌刊行以前から刊行期間中にかけて展開してきた建 築家との共同作業という実験結果でもあった。

パリのレオンス・ローゼンベールグで, 1923 年 10 月 15 日〜11月 15 日に開かれた『くデ・スティル〉建築 展』 ${ }^{48)}$ のための共同作業は，彼が建築を総合的な作業之 して学び始めるきっかけとなる。この建築展以前の共同 作業におけるドゥースブルフの役割は，建物表面におけ る色彩計画のみであったのに対して；建築展では建築に おける色彩, 空間, 形態なよ゙の総合的な関係にまで及ん でいる。ドゥースブルフは,「新しい建築は開放的である。
全体は一つの空間からなり，その空間は，機能上の要求 に従って分割されていく。このような分割は，内部では; 仕切り面 (separating planes), 外部では, 保護面 (sheltering planes)によって生じる。前者（仕切り面） は，空間を多様で機能的に相互的に分割する。言い換え れは，仕切り面の可動的な間仕切りや平版によって空間 が置き換えられる（屝も，この範囲に含まれる）」年) と 言う。この引用文は，〈デ・スティル〉建築に関して論 じる時しばしば取り上げられる重要な言説であり, ドゥースブルフの建築観を簡潔・明確に表わす言説であ る。それは, 建築空間の「開放」や「分割」の概念を示 している。このようなドゥースブルフの見解は, それま での建築思想には見られない, 彼独自の建築への接近と いえる。彼の「空間形態」 space formation ${ }^{50)}$ という言 説を見ても，空間形態の概念を空間と形態の個別的な性 質としてとらえず，要素間の等価的な対立やその要素間 の関係から生れるものとしてとらえていた。ここで, 等 価的対立や関係は，形と線によって空間を制限すること ではなく，空間を分割することによって開放すると考え られている。ドゥースブルフは，建築における「囲い込 み（壁）を崩壊させ，われわれは内部と外部のデュアリ ティを廃止してきた」吕と言う。この言説には, 建築に おける空間のデュアリティ, 内部空間と外部空間を統合 化しようとするドゥースブルフの開放や分割の概念が明 確に読み取れる。このような空間形態への接近は,ドゥー スブルフの偶然の発想からではない。

ここで, この言説が, ドゥースブルフの共同体意識と ビう関わっているかどうかを，III章で論じたデュアリ ティの概念に，さらに，検討を加えて考察することにす る。ドゥースブルフの様式への意識の出発点は, あらゆ るデュアリティ現象をいかに和解, 合意, 統合できるだ ろうかという関心にあった。つまり，これまで取り上げ た「個人二他者」の関係,「個と普遍との均衡のとれた 関係」「両極性の和解」「多極性の合意」「デュアリティ 破壊」への意志が，建築まで拡張されようとしていた。 例えば,ドゥースブルフは,「将来の建築は, デュアリティ を破壊しなければならない。(中略）この作業で, 機械 的で合理的な構造とか思索的で美学的な方法よりも, 創 造的な構造 (creative constructive) を通じて表現す る」年) と語っている。このような建築のデュアリティへ の接近に関して，ドゥースブルフの『日記』(1928.5.1) は,「建築は, 象徵的 (figurative)でなく, 中庸的 (neutral) であるべきである。よ゙んな場合でも, 絵画的方法 (pictorial mean) を取るべきではない」兮)と述べてい る。この言説によって，III章でも取り上げたように，モ ンドリアンの新しい造形におけるデュアリティ概念と, ドゥースブルフのそれと根本的にずれていることが分か る。言い換えれば，ここでの彼の言説は，建築の表現方 
法が、絵画のそれと違うと言うことと、これまでの表現 方法に対する反省的な一面を示している。また，ドゥー スブルフは，「建築において個々の分離された定型への 考慮より, 建築と関係しているあらゆる要素（例えば, ディティール, 構造, 創造性, 経済など) の問題を考虑 すべきである ${ }^{54)}$ と言い，また，「それゆえに，例えば， 建築へ単一的な観点から接近し, 合理的で構造的な態度 か純粋で創造的な態度のどちらかを選ぶなら，その結果 は，一方だけのものになるか貧弱なものになるかであ る ${ }^{551}$ と言う。この言説の注目すべき点は，建築は絵画 のような限定された範囲における問題ではなく, 拡張さ れ，開放され，すべてを考慮したものであるべきである と理解していることである。これまで, ドゥースブルフ の共同体意識が，建築にまで広がっていることが分かっ た。こうした意識は,ドゥースブルフが建築の問題を考 える時, また, 時代が要求している建築や将来の建築は ぞうあるべきかを考える時にも表われているので， ドゥースブルフの共同体意識の下にある建築観を，以下 で考察する。

ドゥースブルフは, 『新しい建築とその結果』(1930) という記事で, オーストリアのホフマン様式とオランダ のウェンディンヘンとを取り上げて非難し，彼自身の建 築に関する見解を次のように語っている。「建築への正 しい接近は，ホフマニズム（Hoffmannism）の唯物主義 的・構造的な努力ではなく, ウェンディンヘン (Wendingen) の装飾的・思弁的態度でもないところ に位置づけることである」 ${ }^{56)}$ と言う。ドゥースブルフは, 建築造形の問題を個々の性格や様式によってとらえるも のと考えず，前向きの姿勢や革新的な概念の中での時代 様式の必要性を強調し，また，建築への正しい接近の方 法として,「建築は, 科学的課題である。その課題の解

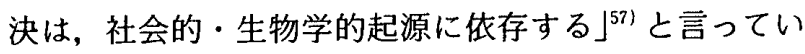
る。こうしたドゥースブルフの建築観は, 時代の要求に 応じるべき思想や建築は, 自然や過去の形式あるいは個 性的で個人的な意志によらず，科学的で生産的な方法に よって接近すべきとの認識に基づいていた。つまり, 彼 は建築を個人的な性格としての認識より, 社会意識の生 成物としてとらえていた。また, 彼は, 「芸術, 宗教, 哲学は, 共に発展する。それらは, 同時代の科学的発見 によって制約される。もちろん, 建築は, 科学的な構成 要素なしに考えられない。建築における最も大きな役割 は, 荷重と支柱, 光と空間などの計算によって成立する。 光の配分と空間の分割は,科学的な基礎の上に成り立つ。 純粋に機能的な有機体は, 数学によって調節される。ま た，その上に, 創造的な意志を受けた時, 計算は, モ二ュ メンタルな美となる」 ${ }^{58)}$ と語る。前に述べたように, ドゥースブルフは科学的な思考を, 新しい生活, 文化, 時代精神, それに新しい美学を形成する基本的な基盤と
してとらえていた。また，彼は，建築の科学的な思考に 加え, 諸現象との関わりを重要視する。彼は, 「建築的 な手段の正確な適用のために, 様々な芸術の相互制御は, 不可避である。そして，それは要素建築を生産する」 ${ }^{599}$ と言い, 建築だけの問題ではなく, 建築と他芸術との並 行的発展を強調していた。こうしたドゥースブルフの意 識から，彼の建築観における社会性を知ることができる。

また，彼は，建築への科学的な接近だけを考えていた のでなかった。建築物としての住宅の概念に対して、「も し住宅がただ住むため (only to live in) であるといわ れるならば，住宅が生活（living）をよ゙う定義するかを 問うべきである。生活は，私たちの身体的なものだけで はなく、私たちの精神治な活動に対しても，関係する機 能である $ل^{60)}$ と言う。ここで, 彼は住宅における生活の 中で，身体と精神の統合を強調する。こうした住宅に関 する言説には，III章で論じた普遍的なデュアリティ概念 が見られ，またそれらを統合するには，センスス・コム 二スのような全体的な知覚が要求されていることが分か る。また，彼は，同じ時期にくデ・ステイル>運動と対 立的な面を見せたアムステルダムスクール (Amsterdam school）を取り上げ, 彼らの時代遅れの表現を笖意的で 気まぐれな形と見做し，それが建築や社会に悪い影響を 与えると箃しく警告している。この言説で注意深く検討 すべき点は, アムステルダム派の個別性, 伝統性, 地域 性の理念に制約された建築は, 現在, 諸芸術や科学の発 展が進む段階で, 建築の表現方法だけが遅れる現象を招 きかねないという指摘である。こうしたドゥースブルフ の意識には，建築によって，時代のあらゆるものに取り 組んで解決しようとする創造的な意志が見られる。 ドゥースブルフの言説に, 共同体意識の自覚なしにつく られた建築は考えられず，また将来の建築造形は客観的 な方法に従うべきとの認識が見られた。ドゥースブルフ の共同体意識は,「エレメンタリズム」の理念まで発展し， 彼の建築観の基盤となり，〈デ・スティル〉運動を建築 運動へ変える要因となった。ドゥースブルフは,「エレ メンタリスム宣言」(1926) で,「エレメンタリスムは, これらのシステムを拒否し，精神・社会的な混沌の中で， 自然一社会と人間の精神一個体の総体的な構造区分に関 するその基本的な原現を見出す ${ }^{611}$ と言っている。また， 〈デ・スティル〉最終号『エレメンタリズム』(1930) では，「完全な作品は，第一に我々が，まず, 我々の個 性を放棄した時に創造されるのである。普遍的なものは， 我々の個性の背後に存し, 衝動は不変の価値之重要性を もつ作品を生み出さなかった」 ${ }^{621}$ と言い，また，「個人 性 (individuality) を構成 (composition) と同じよう な存在理由 (raison d'etre) と見るのに対して, 構造 (construction) を現在性として見做している。(中略) 構成は, 形態, 色彩, 均衡関係においての個人的な多様 
性を指しているが，構造は，形態，色彩，関係性の総合 体 (synthesis) や安定性を意味している。これは，超 個人的な接近 (supra individual approach) によって生

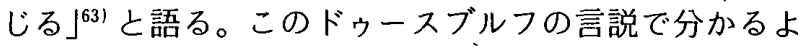
うに，『エレメンタリズム』とは，個性の放棄，そして 社会への接近の上に，構造的な概念を持って現実化され るものであって，共同体意識（超個人的な接近）によっ て生まれるものである。また，ドゥースブルフは，『新 しい建築とその結果』(1930) で,「様式 (style) は, 絵画，装飾，個人住宅のような個人的な対象としての創 造的な作業によらない。都市地区，超高層ビル，空港は 共同体的研究と経済的環境によって進む。つまり，様式 は，もはや手作業とは関係しない影語る。

これまで, 〈デ・スティル>誌後半期におけるドゥ一 スブルフの言説に対する考察で，彼の言説に共同体意識 に基づく建築観がいかに多かったかを論じた。

\section{むすび}

本研究は, ドゥースブルフがくデ・スティル＞誌の刊 行期において発した様々な言説の特徵を共同体意識と位 置付け, それの形成と変化過程を通じて，ドゥースブル フの建築観を検討したものである。

ドゥースブルフの「個人は他者なしには存在し得ない」 という言説の背景は, 古くからの哲学者の課題であった デュアリティの共存関係までに関わっている。筆者は, 彼らが「自亡他」の関係を形成するのにおいて，センス ス・コムニスが要求されているという認識に注目する。 また，ドゥースブルフは，20世紀初めの芸術家たちの 時代精神に基づき，自ら共同体を形成する手段として雑 誌の刊行に取り組み始め, 共同体をくデ・スティル>運 動の理念と見なす。ところが, ドゥースブルフの共同体 意識は, 〈デ・スティル〉誌前半期にかけて様式への意 志に転移され，またくデ・スティル〉誌中期から建築に 関する言説に変化し，〈デ・スティル>誌後半期になつ て，エレメンタリズムまでに拡張する。

つまり,ドゥースブルフの共同体意識は, <デ・スティ ル>誌刊行期の言説の中心的な課題となり, 彼の建築へ の関心によって変化し続けた後, ドゥースブルフの建築 観として蘇ったのである。いずれにしても，ドゥースブ ルフは, 新しい建築への接近を, 個人主義の代わりに, 共同体意識によって求めようとしていたのである。

なお，本稿を作成するにあたり横浜国立大学山田弘康 教授の御指導を得ました。記して感謝申し上げます。

注

1) Nancy J. Tory: The De Stijl Environment, The MIT Press p. 194 199, 1983

2) Hannah L. Hedrick: Theo van Doesburg(Propagandist and Practitioner of the Avant-Garde, 1909 1923),
UMI RESEARCH PRESS p. 1,1980

3）本論文では, ドゥースブルフが, 画家, 彫刻家, 建築家 などの芸術家的な性格より，哲学者，批評家，講演家， 理論家，詩人，小説家などの文筆家的な性格を強く持っ ていたことからこれらを総称して，筆者は「言説家」 と呼ぶ。

4. Ad Petersen ed. : De Stijl 1, Athenaeum, Amsterdam Bert Bakker, Den Haag Pork \&. Van Gennep, Amsterdam Complete Reprint, 1968, p. 4 (Theo van Doesburg :De Stijl, I, p. 2, 1,1917。ここで，「共同体」という 言説が初出する。

5) H. L.C. Jaffe : De Stijl, Thames and Hudson, London, p. 99, 1970 (赤根和生訳 [抽象への意志, モンドリ アンとくデ・スティル〉」朝日出版社, 1984）を参照し た筆者の訳文，以下，同様）

6）崔在錫「テオ・ファン・ドゥースブルフの共同体意識に ついて」, 1991 年 1 月日本建築学会関東支部研究発表会, p. 257 260, 1991。この論稿では, テオ・ヴァン・ドゥー スブルフの共同体意識をアリストテレス, カント,デカ ルトなどの共通感覚の原理に当てはめて述べている。

7) Joost, Baljeu: Theo van Doesburg, Studio Vista, p. 19,1974

8) Allan Doig: Theo van Doesburg(Painting into architecture, theory into practice), Cambridge Universi: ty Press, p. 30, 1986 (Ad Petersen ed. : De Stijl 1, op. cit., pp. 3 4)

9) De Stijl(H. L.C. Jaffe), op. cit., p. 220

10）田中 喬「近代集団・時間」曰本建築学会報告集, 第 89 号, p. 478 , 昭和 38 年

11） E・フッサール「幾何学の起源】田島節夫訳, 青土社, p. 267, 1988

12）共通感覚は, 古代ギリシヤのアリストテレスのコイネ・ アイステーシス (koine aisthesis) の言葉から由来する。 アリストテレスは,「われわれの人間は, 同じ種類の感覚, たとえば視覚相互や昧覚相互の間だけではなく, 異なっ た種類の感覚，たとえば視覚と味覚の間でも，互いにそ れらを比較したり識別したりすることができる。（中略） 感覚すべての領野を統一的にとらえる根源的な感覚能力, つまりく共通感覚〉でなければならない」と語る（中村 雄二郎「共通感賞論」岩波現代選書, p. 8，1979, こうし たアリストテレスの原理は，その後，様々な形をとって， たとえば,テカルトの「人間共同体」,ルソーの「第六感」, カントの「超越論」などのような姿として表わされる。

13）共通感覚論, op cit., p. 7

14）カントは，センスス・コムニス (sensus communis) を 趣味判断の前提になるものと考え，概念に従って判断す るコモン・センス (common sense) と区別している。ま た，彼は「共通感覚は，経験に基づいて設定することは 決してない。この共通感覚の本旨は，一種の当為を含む ような(しかし概念によらない) 判断の確立にあるから である」と言う。(イマヌエル・カント「判断力批判」篠 田英雄訳，岩波文庫・上, p. 123)

15）これは,カントの「判断力批判】(第 40 節) でのセンスス・ コムニスの三つの段階の中の一つとして取り上げられて いる。その三つの段階とは,「(一)自ら考えること(悟性)。 (二）あらゆる他人の立場に立って考えること (判断力)。 
（三）常に自己に矛盾しないように考えること（理性）」 を指す。(イマヌエル・カント「判断力批判】(カント著 作集・4)，大西克禮訳，岩波書占，昭和 7 年, p. 266

16) Immanuel Kant : Kritik der Urteilskratft, Leipzig, p. 144, 1924

17) Carel Blotkamp ed. : De Stijl (The formative years, 1917 1922), Charlotte I. Loeb and Arthur L. Loeb 英 訳, The MIT Press, p. 4, 1986

18）W．カンディンスキー「芸術における精神的なもの」西 田秀穂訳，美術出版社，pp. 60 61，1979

19) Theo van Doesburg (Joost Baljeu), op. cit., p. 19

20) De Stijl (Carel Blotkamp ed.), op. cit., p. 5

21) Ibid.

22）ドゥースブルフは, 詩人 Antony Kok, 画家 Erich de Wichmam, Januus de Winter, W. Huszar, P. Mondrian, Alma, 古典学者 G. Brinkgreve, 建筑家 J. J. P. Oud, 哲学者 Schoenmaek らと出合う。

23）ドゥースブルフは, 〈デ・スティル>グループを結成す る前に, 三つの協会; Haarlem での Thans 協会 (1916/2, 以下，創立年/月/日を指す), Amsterdam での De Anderen 協会 (1916/3/24), Leinden での De Sphinx 協 会 $(1916 / 3 / 24)$ を創立し，それぞれの中心になって活躍 する。

24）掘口捨己「現代オランダ建築」鹿島出版会, 原典不明, pp. $137 \sim 138,1978$

25） R. バンハム『第一機械時代の理論とデザイン」石原達二, 增成隆士訳，鹿島出版会，p. $208 ，$ 昭和 51 年

26) Theo van Doesburg (Hannah L. Hedrick), op. cit., p. 83

27) Ibid

28) De Stijl (H. L.C. Jaffe), op. cit., p. 9

29) Ibid.

30) De Stijl (Ad Petersen ed.), op. cit., p. 3 4

31) Theo van Doesburg : principle of Neoplastic Art, Lon don Lund Humphries, Janet Seligman 英訳, p. 5, 1969, (Neue Bauhausbucher, Mainz und Berlin, 1925)

32) Ibid

33) Ibid.

34）ウルリヒ・コンラーツ編「世界建築宣言文集】阿部公正訳, 彰国社, p. 42, 1970

35）アール・ヴィヴァン編「モンドリアンと〈デ・スティル〉 建築」アール・ヴィヴァン (26 号), 西武美術館, p. 185,
昭和 62

36) H. L. C. Jaffe : De Stijl-1917 1931 (the Dutch contribution to morden art), The Belknap Press of Harverd University Press, p. 19, 1986, (Ad Petersen ed. : Destijl 1, op. cit., p. $600 \sim 602$ )

37) De Stijl (H. L.C. Jaffe), op. cit., p. 149

38) Ibid., p. 181

39) De Stijl (Ad Petersen ed.), op. cit., p. 5

40) H. L.C. Jaffe : De Stijl•1917 1931, BELKNAP/ HARVARD, 1986 , p. 58

41) De Stijl (H. L.C. Jaffe), op. cit., p. 159

42) Theo van Doesburg (Joost Baljeu), op. cit., p. 196

43) Principle of Neoplastic Art: Theo van Doesburg, op. cit. , p. 21

44) De Stijl (H. L.C. Jaffe), op. cit., p. 192

45) Ibid., p. 190

46）「モンドリンと〈デ・スティル〉建築」アール・ヴィヴァ ン編, op. cit., p. 2

47) De Stijl (H. L. C. Jaffe), op. cit., p. 172

48) The De Stijl Environment (Nancy J. Tory), op. cit., p. $200 \sim 201$

49) De Stijl (H. L.C. Jaffe), op. cit., p. 186

50) Principles of Neo-plastic Art (Theo van Doesburg) op. cit., p. 7

51) De Stijl (H.L.C. Jaffe), op. cit., p. 192

52) Theo van Doesburg (Joost Baljeu), op. cit., p. 195

53) Mildred Friedman ed. : De Stijl-1917 1931 (Visions of Utopia), Abbeville Press, p. 88, 1988 (Sergio Polaano : De Stijl/Architecture=Nieuwe Beelding)

54) De Stijl (H.L.C. Jaffe), op. cit., p. 190

55) Theo van Doesburg (Joost Baljeu), op. cit., p.191

56) Ibid

57) Ibid

58) Theo van Doesburg (Allan Doig), op. cit., p. 152

59) Theo van Doesburg (Joost Baljeu), op. cit., p. 191

60) Ibid.

61) De Stijl (H. L.C. Jaffe), op. cit., p. 210

62) Ibid., p. 238

63) Theo van Doesburg (Joost Baljeu), op. cit., p. 184

64) Ibid., p. 196

(1991 年 3 月 10 日原稿受理, 1992 年 1 月 21 日採用決定） 